JAMP: Jurnal Adminitrasi dan Manajemen Pendidikan

Volume 4 Nomor 1 Maret 2021, Hal :61 - 71

Tersedia Online di http://journal2.um.ac.id/index.php/jamp/

ISSN 2615-8574 (online)

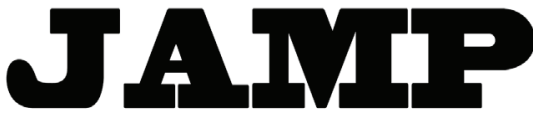

JURNAL ADMINISTRASI DAN MANAJEMEN PENDIDIKAN

\title{
ANALISIS KESIAPAN PESERTA DIDIK DAN GURU PADA ASESMEN NASIONAL (ASESMEN KOMPETENSI MINIMUM, SURVEY KARAKTER, DAN SURVEY LINGKUNGAN BELAJAR)
}

\author{
Deni Ainur Rokhim ${ }^{1}$ \\ Binti Nuriyati Rahayu ${ }^{2}$ \\ Laila Nur Alfiah ${ }^{3}$ \\ Ristiwi Peni ${ }^{4}$ \\ Bambang Wahyudi ${ }^{5}$ \\ Asnan Wahyudi ${ }^{6}$ \\ Sutomo $^{7}$ \\ Hayuni Retno Widarti ${ }^{8}$ \\ 1,4,5,6,7, SMAN 3 Sidoarjo \\ Email: deniainurrokhim@gmail.com
}

${ }^{1,2,3,8}$ Fakultas Matematika dan Ilmu Pengetahuan Alam, Universitas Negeri Malang

\begin{abstract}
This study aims to see and analyze the readiness of teachers and students in the National Assessment. The research was conducted with a survey method through the distribution of google form questionnaires. The data obtained were analyzed using descriptive statistics. The results of the study group of students showed that $46.6 \%$ of students understood national assessment and $53.2 \%$ of students did not understand well about national assessment. This is due to the fact that the education unit has not yet disseminated the implementation of the national assessment which has three instruments including the Minimum Competency Assessment (AKM), learning surveys and learning environment surveys. The results of the teacher group research stated that $75 \%$ of teachers understood national assessment and $25 \%$ of teachers did not understand national assessment. A national assessment is carried out to evaluate the input, process, and quality of teaching and learning in the classroom so as to improve the quality of Indonesian education.
\end{abstract}

Keywords: analysis of the readiness of teachers; students; national assessment

\begin{abstract}
Abstrak: Penelitian ini bertujuan untuk mengetahui dan menganalisis kesiapan guru dan peserta didik dalam Asesmen Nasional. Penelitian dilakukan dengan metode survei melalui penyebaran angket google form. Data yang diperoleh dianalisis menggunakan statistik deskriptif. Hasil penelitian kelompok peserta didik menujukkan bahwa 46,6\% peserta didik memahami mengenai asesmen nasional dan 53,2\% peserta didik belum memahami dengan baik mengenai asesmen nasional. Hal ini disebabkan karena satuan pendidikan terkait belum melakukan sosialisasi penerapan asesmen nasional yang memiliki tiga instrumen penilaian meliputi Asesmen Kompetensi Minimum (AKM), survey belajar, dan survey lingkungan belajar. Hasil penelitian kelompok guru menyatakan bahwa $75 \%$ guru memahami mengenai asesmen nasional dan $25 \%$ guru belum memahami mengenai asesmen nasional. Asesmen nasional dilakukan untuk melakukan evaluasi terhadap input, proses, dan kualitas belajarmengajar di kelas sehingga meningkatkan mutu pendidikan Indonesia.
\end{abstract}

Kata kunci: analisis kesiapan guru; peserta didik; asesmen nasional 
Penilaian (asesmen) hasil belajar merupakan langkah yang dilakukan untuk mengukur hasil belajar peserta didik. Penilaian hasil belajar oleh pendidik bertujuan untuk memantau dan mengevaluasi proses, kemajuan belajar, perbaikan hasil belajar peserta didik secara berkesinambungan, serta digunakan pemerintah untuk mengambil kebijakan dalam pendidikan (Permendikbud Nomor 104 Tahun 2014; Wilson, 2018). Penilaian memerlukan suatu instrumen (alat) yang digunakan agar hasil yang didapatkan objektif untuk mengukur hasil belajar siswa dengan tepat, baik berupa tes maupun tes (Arifin, 2011). Pada skala internasional, instrumen penilaian (asesmen) yang digunakan adalah PISA (Programme for International Student Assessment) dan TIMSS (Trend In International Mathematics And Science Study). Berdasarkan data OECD (2018), peringkat nilai PISA Indonesia tahun 2018 dalam tiga aspek yang dinilai yaitu membaca (peringkat 72 dari 77 negara), matematika (peringkat 72 dari 78 negara), dan sains (peringkat 70 dari 78 negara). Dalam 10-15 tahun terakhir, nilai Indonesia cenderung stagnan. Sementara, nilai TIMSS Indonesia yang dilakukan pada peserta didik kelas 4 tahun 2015 berada pada peringkat ke 44 dari 49 negara pada aspek matematika dan peringkat ke 46 dari 49 negara pada aspek sains (Hadi \& Novaliyosi, 2018; Mullis, dkk., 2016a; Mullis, dkk., 2016b).

Selain TIMSS, hasil PISA sering dijadikan rujukan dalam pengambilan keputusan di berbagai negara termasuk di Indonesia (Tan, 2017). Pada tahun 2019, Menteri Pendidikan dan Kebudayaanmenyampaikan secara resmi bahwa Ujian Nasional (UN)pada tahun 2021 akan dihapuskan dan digantikan dengan Asesmen Nasional (AN) dalam Program Merdeka Belajar. Asesmen nasional didasarkan pada model asesmen yang telah dilakukan oleh PISA dan TIMSS. Asesmen nasional dilakukan bertujuan untuk mengubah paradigma evaluasi pendidikan di Indonesia sebagai upaya mengevaluasi dan memetakan sistem pendidikan berupa input, proses, dan hasil bukan mengevaluasi capaian peserta didik yang sebelumnya digunakan dalam Ujian Nasional. Asesmen nasional akan dilakukan pada jenjang pertengahan sekolah yaitu kelas 5 untuk tingkat SD/MI, kelas 8 untuk tingkat SMP/MTs, dan kelas 11 untuk tingkat SMA/MA/SMK sehingga mendorong guru dan kepala sekolah memperbaiki mutu pembelajaran.Kebijakan tersebut diharapkan dapat memberikan kesempatan pelaku pendidikan untuk memperbaiki pembelajaran di tahun berikutnya (Kementerian Pendidikan dan Kebudayaan, 2019).

Asesmen Nasional 2021 yang digunakan untuk pemetaan mutu pendidikan di Indonesia terdiri dari tiga bagian yaitu Asesmen Kompetensi Minimum (AKM), Survey Karakter, dan Survey Lingkungan Belajar (Kementerian Pendidikan dan Kebudayaan, 2020). Asesmen Kompetensi Minimum digunakan untuk mengukur hasil belajar kognitif meliputi literasi membaca dan literasi numerasi (matematika). Sementara survey karakter digunakan untuk mengukur hasil belajar emosional yang terwujud dalam Profil Pelajar Pancasila agar pelajar Indonesia memiliki kompetensi global dan berperilaku sesuai dengan nilai-nilai Pancasila. Jika Asesmen dan Kompetensi Minimum dilakukan oleh peserta didik, survey lingkungan belajar dilakukan pada semua pelaku pendidikan meliputi kepala sekolah, guru, dan peserta didik. Survey lingkungan belajar dilakukan bertujuan untuk memperoleh informasi keadaan sekolah yang sesungguhnya (Pusat Asesmen dan Pembelajaran Kementerian Pendidikan dan Kebudayaan, 2019).

Asesmen Nasional merupakan evaluasi pendidikan yang sangat baru di Indonesia. Ditjen P3GTK Kementerian Pendidikan dan Kebudayaan (2020) telah mulai melakukan persiapan Asesmen Nasional. Pemerintah melakukan uji coba Survey Karakter dan Lingkungan Belajar untuk mengembangkan instrument yang valid dan reliabel pada tanggal 12 Juni 2020 sampai dengan tanggal 24 Juli 2020. Uji coba instrumen Survey Karakter dan Lingkungan Belajar dilakukan pada 22 sekolah dari perwakilan Provinsi Aceh, DKI Jakarta, Sulawesi Selatan, Nusa Tenggara Timur, Papua, dan Papua Barat. Di sisi lain, sebagian besar pelaku pendidikan baik kepala sekolah, guru, dan peserta didik, maupun orangtua masih belum memahami fungsi dan jenis asesmen nasional yang sesungguhnya. Karena dianggap menggantikan UN, asesmen nasional dianggap masih sama dilakukan pada tingkat akhir yaitu kelas 6 untuk tingkat SD/MI, kelas 9 untuk tingkat SMP/MTs, dan kelas 12 untuk tingkat SMA/MA/SMK. Selain itu, asesmen nasional tidak menggunakan pembedaan mata pelajaran seperti halnya Ujian Nasional. Penelitian mengenai kesiapan guru dan peserta didik dalam Asesmen Nasional perlu dilakukan untuk memberi gambaran kesiapan guru dan peserta didik dalam Asesmen Nasional dan menjadi pertimbangan pihak terkait dalam menentukan kebijakan lebih lanjut khususnya dalam pemetaan mutu pendidikan di 
Indonesia, serta perbaikan persiapan pelaksanaan Asesmen Nasional di tahun berikutnya. Oleh karena itu, penelitian ini dilakukan bertujuan untuk mengetahui dan menganalisis kesiapan guru dan peserta didik dalam Asesmen Nasional.

\section{METODE}

Penelitian ini menggunakan metode penelitian survei dengan pendekatan deskriptif kuantitatif. Penelitian survey adalah penelitian yang melibatkan sekelompok individu untuk menjawab sejumlah pertanyaan dalam instrumen, baik melalui pertanyaan wawancara, kuesioner, maupun tes (Fraenkel, dkk, 2012). Langkah penelitian survey yang dilakukan terdiri dari 1) merumuskan masalah dan menentukan tujuan survey, 2) mengidentifikasi subjek penelitian, 3) pemilihan teknik pengumpulan data, 4) pembuatan instrumen, 5) penyebaran instrumen, dan 7) analisis data dan pelaporan.

Data yang diperoleh dari penelitian ini adalah data kualitatif dan kuantitatif Data kualitatif diperoleh dari perspektif pedagang dalam mengisi pertanyaan terbuka, sedangkan data kuantitatif diperoleh dari pendapat pedagang dalam menentukan kriteria jawaban. Teknik pengumpulan data yang digunakan adalah penyebaran angket melalui aplikasi google form. Sampel dalam penelitian terdiri dari 44 guru dan 116 peserta didik di Jawa Timur. Penelitian dilakukan pada bulan Desember 2020 menggunakan penyebaran angket melalui google form. Data yang diperoleh dianalisis menggunakan teknik statistik deskriptif. Teknik statistik deskriptif digunakan untuk menganalisis hasil penelitian tanpa digunakan untuk membuat kesimpulan yang lebih luas atau generalisasi (Sugiyono, 2017).

\section{HASIL DAN PEMBAHASAN}

Penyebaran angket dilakukan melalui aplikasi google from kepada kelompok guru dan siswa di Jawa Timur. Kelompok guru sebanyak 44 responden yang berasal dari berbagai wilayah di Jawa Timur yaitu Bangkalan, Bondowoso, Jember, Malang, Mojokerto, Madiun, Probolinggo, Lumajang, Ngawi, Ponorogo, Pamekasan, Sidoarjo, dan Tulungagung. Kelompok peserta didik sebanyak 116 responden yang berasal dari Sekolah Menengah Atas (SMA) di Jawa Timur.

\section{Kelompok Peserta Didik}

Data hasil angket mengenai pemahaman mengenai istilah asesmen nasional menyatakan bahwa $46,6 \%$ paham (54 responden), 19\% tidak paham ( 22 responden), dan $34,5 \%$ ragu (40 responden) (Grafik 1). Berdasarkan data tersebut menunjukkan bahwa $53,5 \%$ dengan 62 responden belum memahami dengan baik mengenai asesmen nasional. Putri pelajar SMA menyatakan bahwa sekolah belum melakukan sosialisasi mengenai pemberlakuan asesmen nasional meliputi Asesmen Kompetensi Minimum (AKM), Survey Karakter, dan Survey Lingkungan Belajar yang akan dilaksanakan tahun 2021.

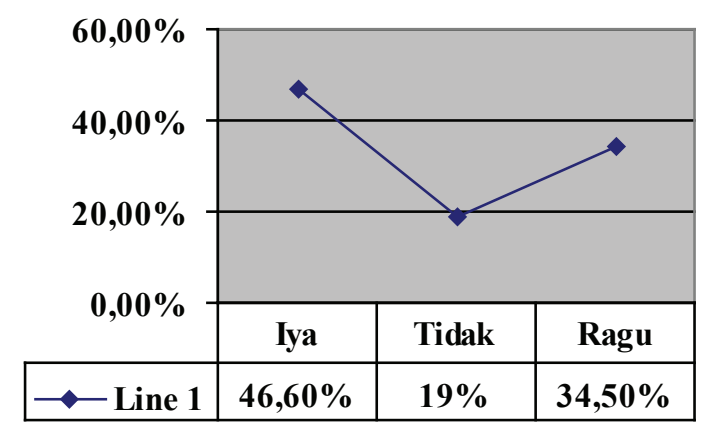

Gambar 1. Pemahaman siswa terhadap penerapan asesmen nasional

Penerapan asesmen nasional membutuhkan dukungan dari satuan pendidikan terkait, agar peserta didik melakukan banyak persiapan untuk menghadapi asesmen nasional. Hal ini disebabkan karena penilaian mutu sekolah, madrasah, dan program kesetaraan pada jenjang dasar dan menengah dinilai 
berdasarkan hasil peserta didik dalam menyelesaikan asesmen nasional (literasi, numerasi, dan karakter) (Kemendikbud, 2020). Hasil penilaian tersebut dapat digunakan untuk melakukan evaluasi terhadap input, proses, dan kualitas belajar-mengajar di kelas. Hasil asesmen nasional tidak menentukan kelulusan peserta didik karena tidak memuat skor atau nilai peserta didik. Kelulusan peserta didik merupakan kewenangan dari pendidik dan satuan pendidikan (Kemendikbud, 2020).

Data hasil angket menyatakan bahwa peserta didik belum memahami dengan baik mengenai asesmen nasional. Peserta didik menganggap penerapan asesmen nasional hanya menggantikan Ujian Nasional (UN) yang dilaksanakan di sekolah untuk tingkat akhir misalnya kelas VI, IX, dan XII. Fikri pelajar SMA menyatakan bahwa penerapan asesmen nasional menggantikan Ujian Nasional (UN) bagi peserta didik yang sedang menempuh sekolah tingkat akhir. Berdasarkan Kemendikbud (2020) asesmen nasional tidak hanya sebagai pengganti Ujian Nasional (UN) yang selama ini hanya menilai aspek kognitif peserta didik, sehingga peserta didik kurang mampu mengembangkan keterampilan berpikir tingkat tinggi (HOTS) melainkan sebagai sarana untuk melakukan refleksi perbaikan mutu pendidikan Indonesia (Kemendikbud, 2020).

Data hasil angket menyatakan bahwa 80 responden menjawab salah mengenai instrumen asesmen nasional dan 36 menjawab benar mengenai instrumen asesmen nasional (Gambar 2). Purnomo pelajar SMA menyatakan bahwa instrumen asesmen nasional yaitu pertanyaan mengenai studi kasus dan Ahmad pelajar SMA juga menyatakan instrumen asesmen nasional yaitu instrumen penilaian sikap. Menurut Kemendikbud (2020) instrumen asesmen nasional meliputi Asesmen Kompetensi Minimum (AKM), Survey Karakter, dan Survey Lingkungan Belajar. Penjabaran makna instrumen asesmen nasional adalah :

1. Asesmen Kompetensi Minimum (AKM) mengukur literasi membaca dan literasi matematika (numerasi) peserta didik,

2. Survey Karakter yang mengukur sikap, nilai, keyakinan, dan kebiasaan yang mencerminkan karakter peserta didik,

3. Survey Lingkungan Belajar yang mengukur kualitas berbagai aspek input dan proses belajarmengajar di kelas maupun di tingkat sekolah (Kemendikbud, 2020).

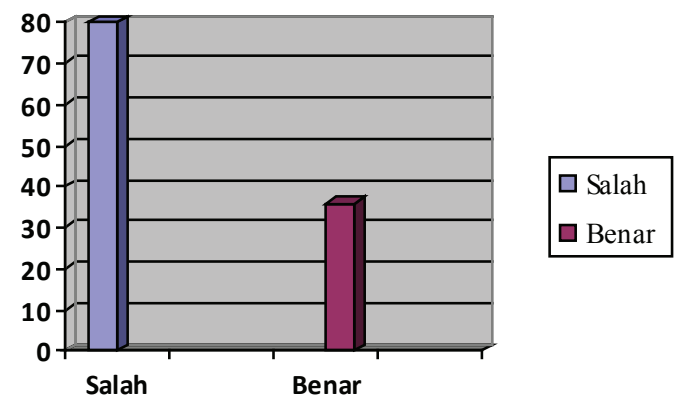

Gambar 2. Hasil pengetahuan peserta didik mengenai instrumen asesmen nasional

\section{Asesmen Kompetensi Minimum (AKM)}

Data hasil angket menyatakan bahwa 20 responden menjawab kurang lengkap dan 80 responden menjawab salah, dan 16 responden menjawab benar dan lengkap mengenai komponen dari literasi membaca dan numerasi yang diukur pada Asesmen Kompetensi Minimum (AKM) (Tabel 2). Arla dan Arina pelajar SMA menyatakan bahwa komponen literasi membaca dan numerasi adalah pemahaman teori konsep secara logika pada materi pembelajaran dan kemampuan memahami, mengevaluasi berbagai jenis teks dan kemampuan berpikir dalam menggunakan konsep,prosedur, fakta, dan alat matematika. Hal ini kurang sesuai dengan kemendikbud (2020) yang menyatakan bahwa komponen literasi membaca meliputi teks informasi dan sastra, menemukan, interpretasi dan integrasi, evaluasi dan refleksi informasi, dan personal, sosial budaya, serta saintifik sedangkan komponen numerasi aljabar, bilangan, geometri, pengukuran, data dan ketidakpastian, pemahaman, penerapan dan penalaran. 


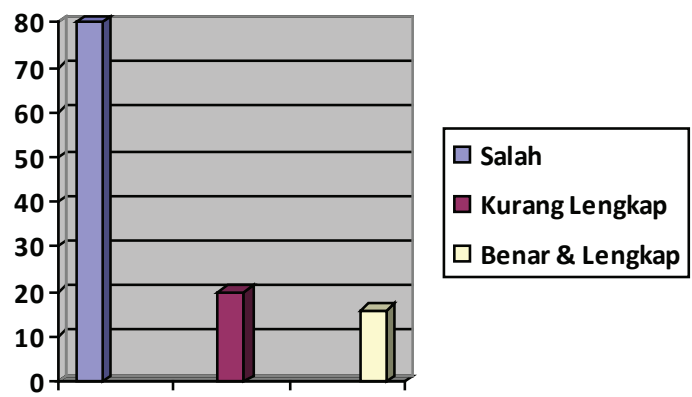

Gambar 3. Hasil pengetahuan peserta didik mengenai komponen literasi dari Asesmen Kompetensi Minimum (AKM)

Berdasarkan Pusat Asesmen dan Pembelajaran (2020) menyatakan bahwa Asesmen Kompetensi Minimum (AKM) memiliki 6 level dengan berbagai beban soal yang berbeda menyesuaikan tingkatan level (Gambar 1). Bentuk soal Asesmen Kompetensi Minimum (AKM) berupa pilihan ganda, pilihan ganda kompleks, menjodohkan, isian singkat, dan uraian (Kemendikbud, 2020).

\begin{tabular}{|lr|}
\hline \multicolumn{2}{|l|}{ Level 1 (Kelas 1 \& 2) } \\
\hline Numerasi (Kelas 2) & 31 \\
& Soal \\
Literasi Teks Fiksi & 21 \\
Literasi Teks & Soal \\
Informasi & 29 \\
\hline Level 4 (Kelas 7 \& 8 ) \\
\hline Numerasi (Kelas 8) & 67 \\
\hline Literasi Teks Fiksi & Soal \\
Literasi Teks & 29 \\
Informasi & Soal \\
\hline
\end{tabular}

\begin{tabular}{|lr|}
\hline Level 2 (Kelas 3 \& 4) \\
\hline Numerasi (Kelas 4) & 48 \\
Literasi Teks Fiksi & 24 \\
Literasi Teks & Soal \\
Informasi & 21 \\
\hline Level 5 (Kelas 9 \& 10) \\
\hline Numerasi (Kelas 10) & 62 \\
\hline Literasi Teks Fiksi & 28 \\
Literasi Teks & Soal \\
Informasi & 40 \\
\hline
\end{tabular}

$\begin{array}{lr}\text { Level } 3 \text { (Kelas } 5 \text { \& 6) } \\ \text { Numerasi (Kelas 6) } & 47 \\ & \text { Soal } \\ \text { Literasi Teks Fiksi } & 24 \\ \text { Literasi Teks } & \text { Soal } \\ \text { Informasi } & 35 \\ & \text { Soal }\end{array}$

\begin{tabular}{|lr|}
\hline Level 6 (Kelas 11 \& 12) \\
\hline Literasi Teks Fiksi & 11 \\
Literasi Teks & Soal \\
Informasi & 39 \\
& Soal \\
\hline
\end{tabular}

Gambar 4. Tingkatan Level Asesmen Kompetensi Minimum (AKM) (Sumber: Pusat Asesmen dan Pembelajaran, 2020)

Data hasil angket menyatakan bahwa 25 responden menjawab belum mempersiapkan dan 50 responden menjawab melakukan persiapan dengan mengikuti tryout, dan 41 responden menjawab belajar dengan rajin, bersungguh-sungguh, dan mulai mengenali tipe-tipe soal (Gambar 5). Berdasarkan hasil telaah jawaban peserta didik beberapa sekolah di Jawa Timur telah melaksanakan sosialisasi mengenai asesmen nasional. Fahri dan Novia seorang pelajar SMA menyatakan bahwa pihak sekolah telah mengadakan sosialisasi untu menjelaskan lebih detai mengenai AKM dan sekolah telah memberi arahan dan sosialiasi AKM dengan melaksanakan beberapa tryout, latihan, serta simulasi AKM. Hal ini mampu mempersiapkan siswa untuk menghadapi penilaian Asesmen Kompetensi Minimum (AKM) yang akan dilaksanakan tahun 2021.

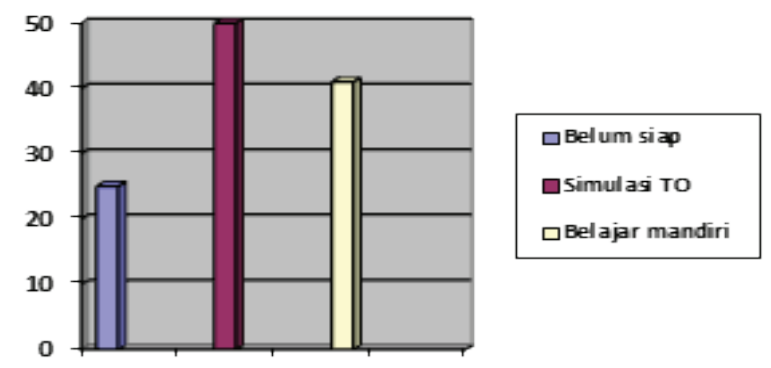

Gambar 5. Hasil kesiapan peserta didik dalam menghadapi penilaian Asesmen Kompetensi Minimum (AKM) 


\section{Survey Karakter}

Data hasil angket menyatakan bahwa 18 responden menjawab tidak tahu mengenai survey karakter, 10 orang menjawab salah, 60 responden menjawab kurang lengkap, dan 20 responden menjawab lengkap (Gambar 6). Faniah dan Bella pelajar SMA menyatakan bahwa survey karakter dilakukan untuk mengetahui karakter siswa selama pembelajaran berlangsung dan untuk mengetahui kondisi ekosistem karakter para murid di sekolah terkait pelaksanaan asas Pancasila dalam interaksi antar peserta didik di sekolah.Berdasarkan Kemendikbud (2020) menyatakan bahwa survey karakter dilakukan untuk mengukur hasil belajar emosional yang mengacu pada Profil Pelajar Pancasila dimana pelajar Indonesia memiliki kompetensi global dan berperilaku sesuai dengan nilai-nilai Pancasila.

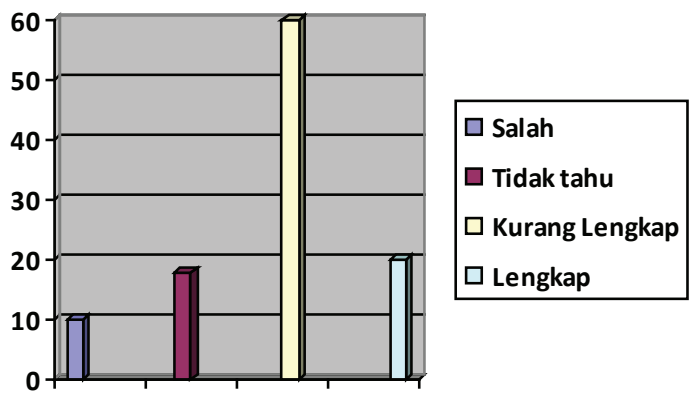

Gambar 6. Hasil pengetahuan peserta didik mengenai survey karakter

Data hasil angket menyatakan bahwa 80 responden menjawab kurang lengkap, 25 responden menjawab lengkap, dan 11 responden menjawab tidak tahu mengenai bagaimana cara menerapkan 6 karakter profil pelajar pancasila (Tabel 5).

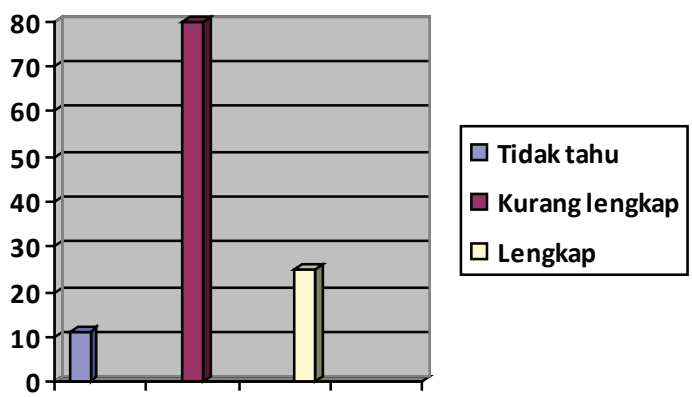

Gambar 7. Hasil pengetahuan peserta didik mengenai 6 karakter profil pelajar pancasila

Muhammad dan Nabila pelajar SMA menyatakan bahwa 6 karakter profil pelajar pancasila adalah bersosialisai dengan baik, belajar dengan optimal, memilih lingkungan pergaulan yang baik, menerapkan pendidikan karakter dan menjalankan ibadah shalat tepat waktu, membantu orang tua dalam menyelesaikan pekerjaan rumah seperti menyapu, mengepel dan lain-lain. Berdasarkan Kemendikbud (2020) profil pelajar pancasila memiliki 6 karakter (Gambar 8). Keenam karakter tersebut dapat diimplementasikan di lingkungan sekolah, rumah, dan masyarakat.

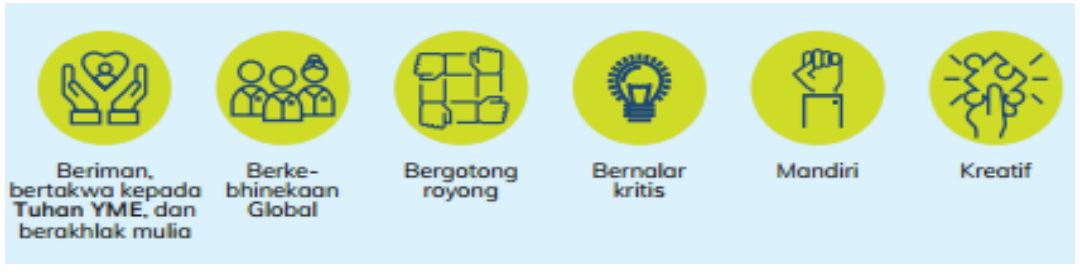

Gambar 8 Karakter profil pelajar pancasila (Sumber: Kemendikbud, 2020) 


\section{Survey Lingkungan Belajar}

Data hasil angket menyatakan bahwa 35 responden menyatakan nyaman, menyenangkan, dan menarik, 50 responden menyatakan cukup nyaman, kurang efektif, dan membosankan, 21 menyatakan biasa saja, dan 10 responden menyatakan tidak tahu mengenai kondisi lingkungan belajar bagi peserta didik (Gambar 9). Kondisi pandemi Covid-19 mengharuskan Pembelajaran Tatap Muka (PTM) dilakukan secara dalam jaringan (daring). Pembelajaran dalam jaringan (daring) memberikan berbagai kesan berbeda kepada masing-masing peserta didik. Beberapa peserta didik mengalami kesulitan dalam mengikuti pembelajaran dalam jaringan (daring) karena peserta didik harus mampu menggali kemampuannya sendiri tanpa pantauan guru secara langsung.

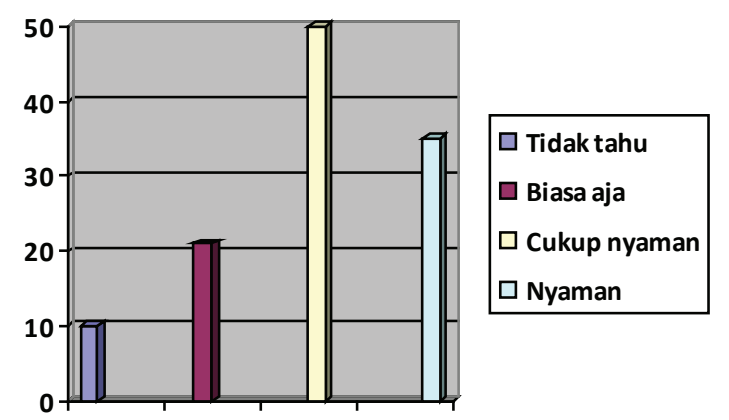

Gambar 9. Hasil survey lingkungan belajar peserta didik

\section{Kelompok Guru}

Data hasil angket mengenai pemahaman mengenai istilah asesmen nasional menyatakan bahwa $75 \%$ paham (33 responden), 4,5\% tidak paham (2 responden), dan 20,5\% ragu ( 9 responden) (Gambar 10). Berdasarkan data tersebut menunjukkan bahwa hanya $25 \%$ dengan 11 responden belum memahami dengan baik mengenai asesmen nasional. Hal ini dapat disimpulkan bahwa guru di Jawa Timur telah mengetahui mengenai rencana penerapan asesmen nasional di tahun 2021.

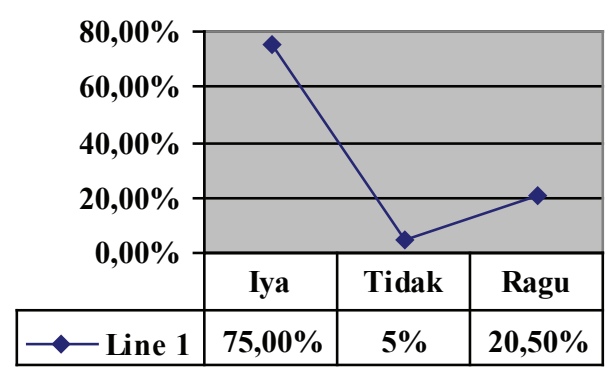

Gambar 10. Pengetahuan guru terhadap penerapan asesmen nasional

Menurut Kemendikbud (2020) menyatakan bahwa peserta asesmen nasional adalah seluruh satuan pendidikan yang terdiri atas: kepala sekolah, seluruh guru, dan murid yang dipilih secara acak dengan stratifikasi sosial ekonomi oleh Kemdikbud. Guru menjadi salah satu peserta asesmen nasional terutama pada instrumen survey lingkungan belajar (Kemendikbud, 2020). Hal ini disebabkan karena hasil peserta didik akan menjadi refleksi atau perbaikan agar guru mampu menciptakan pembelajaran yang berkualitas.

Data hasil angket menyatakan bahwa 9 responden belum memahami dengan benar mengenai tujuan asesmen nasional dan 35 responden sangat memahami tujuan asesmen nasional (Gambar 11). Ahmad dan Rahman menyatakan bahwa asesmen nasional menggantikan Ujian Nasional (UN), sehingga dalam konteks ini asesmen nasional hanya diberikan kepada peserta didik di tingkat sekolah akhir. Dalam hal ini perlu adanya peran menteri pendidikan dan kebudayaan dalam melakukan sosialisasi kembali mengenai tujuan dan hakikat dilaksanakannya asesmen nasional di tahun 2021. 


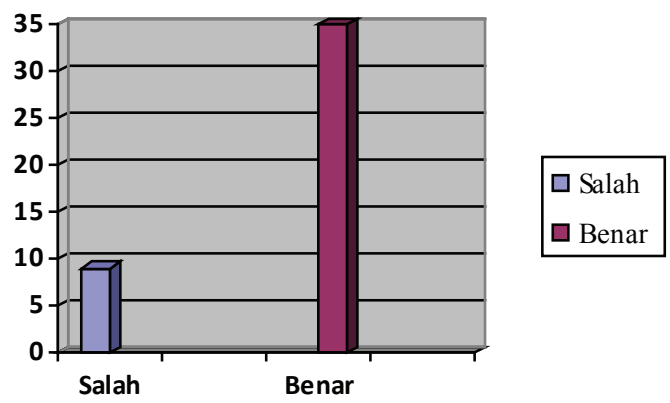

Gambar 11. Hasil pengetahuan guru mengenai asesmen nasional

Data hasil angket menyatakan bahwa 12 responden menjawab salah dan 32 responden menjawab benar mengenai instrumen yang akan digunakan dalam penerapan asesmen nasional (Gambar 12). Salah satu responden menjawab bahwa instrumen asesmen nasional meliputi peserta didik, kepala sekolah, sarpras, dan guru. Hal ini membuktikan bahwa beberapa guru belum memahami secara betul instrumen atau alat yang akan digunakan dalam penerapan asesmen nasional. Instrumen atau alat yang akan digunakan dalam penerapan asesmen nasional untuk mengetahui mutu sekolah dapat dinilai dari tiga instrumen yang digunakan meliputi Asesmen Kompetensi Minimum (AKM), Survey Karakter, dan Survey Lingkungan Belajar (Kemendikbud, 2020).

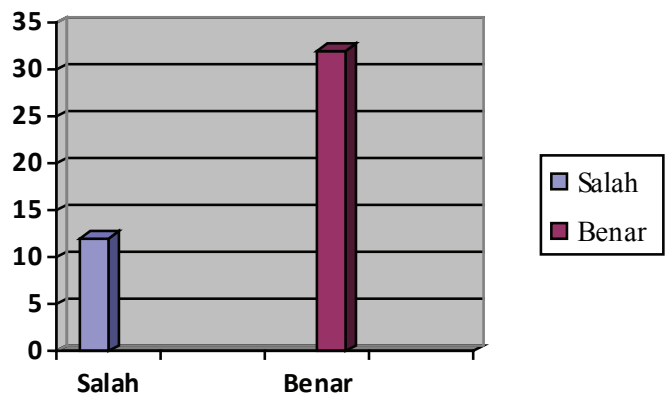

Gambar 12. Hasil pengetahuan guru mengenai instrumen asesmen nasional

Data hasil angket menyatakan bahwa 16 responden menyatakan bahwa persiapan antara asesmen dan Ujian Nasional (UN) sama dan 28 responden menyatakan bahwa persiapan antara asesmen dan Ujian Nasional (UN) berbeda (Gambar 13). Ujian Nasional (UN) hanya dilaksanakan bagi jenjang pendidikan di tingkat akhir misalnya kelas VI, IX, dan XII serta asesmen nasional dilakukan pada peserta didik di kelas V, VIII, dan XI. Maka persiapan yang dilakukan untuk menghadapi Ujian Nasional (UN) dan asesmen nasional berbeda. Hal ini disebabkan karena kisi-kisi Ujian Nasional (UN) mengacu pada pencapaian materi kurikulum dan kelulusan peserta didik sedangkan asesmen nasional dilakukan untuk mengetahui mutu sekolah dan refleksi untuk melakukan perbaikan proses belajar-mengajar di kelas. Asesmen nasional tidak memiliki kisi-kisi materi secara detail layaknya Ujian Nasional (UN). Kisi-kisi asesmen nasional diuraikan secara rinci di website Pusat Asesmen dan Pembelajaran.

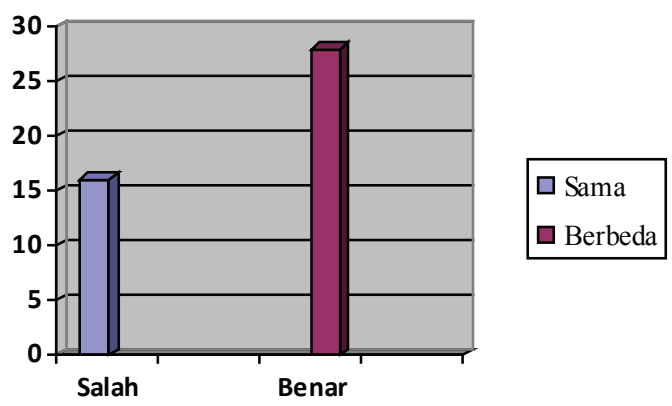

Gambar 13. Hasil mengenai persiapan Ujian Nasional (UN) dengan asesmen nasional 


\section{Asesmen Kompetensi Minimum (AKM)}

Data hasil angket menyatakan bahwa 15 responden menjawab salah dan 29 responden menjawab benar mengenai kemampuan yang akan diukur dalam Asesmen Kompetensi Minimum (AKM) meliputi literasi membaca dan numerasi (Gambar 14).

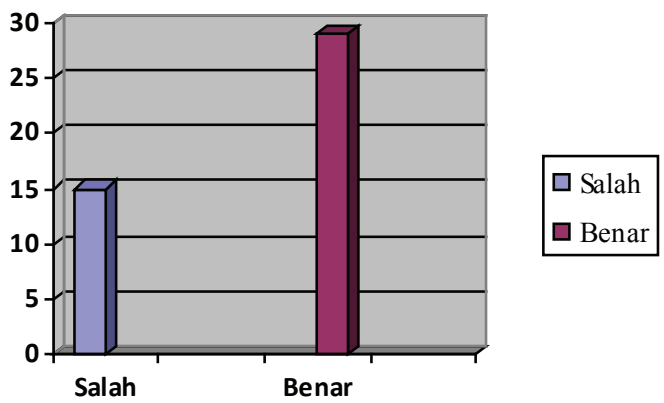

Gambar 14. Hasil pengetahuan guru mengenai indikator Asesmen Kompetensi Minimum (AKM)

Menurut Kemendibud (2020) menyatakan bahwa komponen literasi membaca dan numerasi konten, proses kognitif, dan konteks (Gambar 15). Kemendibud memiliki tujuan untuk meningkatkan minat membaca dan matematika (numerasi) para peserta didik dengan menerapkan penilaian Asesmen Kompetensi Minimum (AKM) karena Indonesia pada tahun 2018 menduduki peringkat ke 72 dari 77 negara (membaca) dan peringkat 72 dari 78 negara (numerasi) (OECD, 2018).

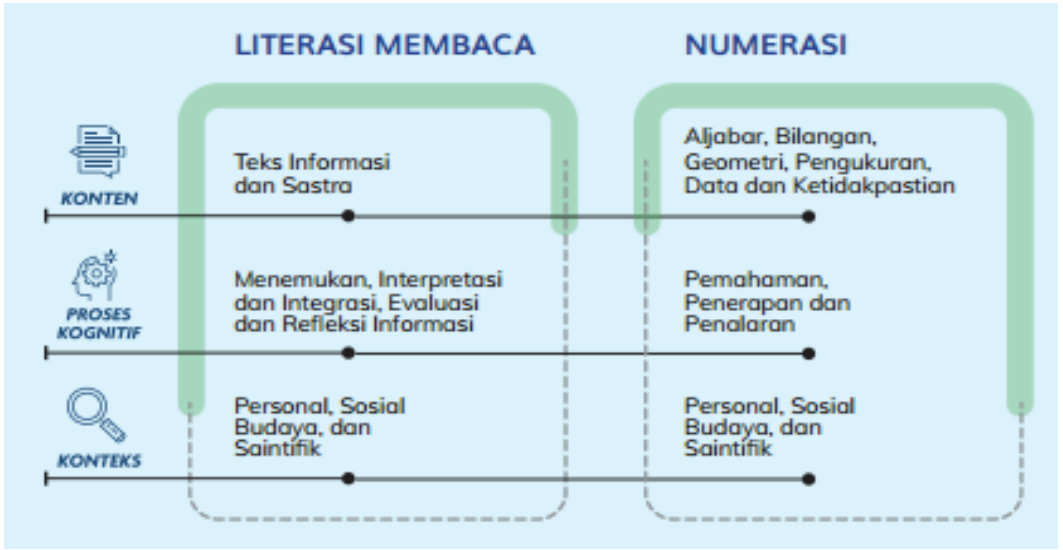

Gambar 15. Komponen literasi membaca dan numerasi

Data hasil angket menyatakan 12 responden belum melakukan persiapan menghadapi Asesmen Kompetensi Minimum (AKM) dan 32 responden telah melakukan persiapan menghadapi Asesmen Kompetensi Minimum (AKM) (Gambar 16). Ruda dan Risa menyatakan bahwa sekolah melakukan sosialisasi mengenai penerapan Asesmen Kompetensi Minimum (AKM) dan melakukan latihan soalsoal HOTS. Salah satu jawaban guru menyatakan bahwa banyak satuan pendidikan belum memahami dengan baik mengenai penerapan asesmen nasional sehingga guru belum mempersiapkan apapun. Kebijakan yang harus dilakukan oleh satuan pendidikan terkait adalah melakukan sosialisasi mengenai penerapan asesmen nasional sesuai dengan kebijakan yang dikeluarkan oleh Bapak Nadiem Makarim. Salah satu persiapan yang dapat dilakukan adalah melakukan tryout menggunakan soal-soal sesuai dengan kisi-kisi Asesmen Kompetensi Minimum (AKM). 


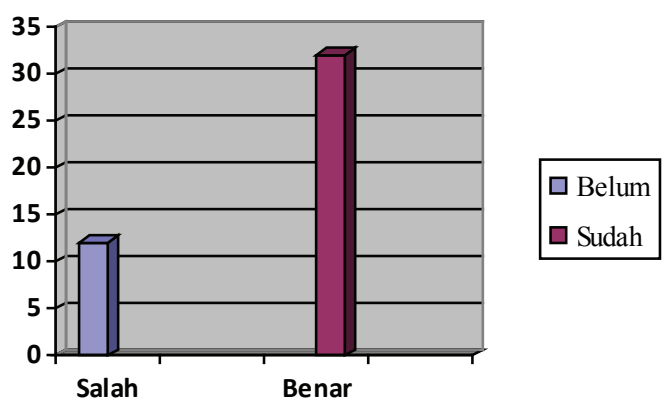

Gambar 16. Hasil mengenai persiapan menghadapi Asesmen Kompetensi Minimum (AKM)

\section{Survey Karakter}

Data hasil angket menyatakan bahwa 44 responden menyiapkan peserta didik untuk menerapkan 6 profil pelajar pancasila. Rahman seorang guru berpendapat dengan merancang pembelajaran yg menerapkan 6 karakter tersebut sistem pendidikan juga harus menerapkan 6 karakter misalnya mengadakan program sholat dhuha, sholat dhuhur berjamaah dalam aspek beriman dan bertakwa dan memberi contoh soal HOTS agar peserta didik mampu menalar dan berfikir kritis. Penerapan 6 karakter meliputi beriman dan bertaqwa, mandiri, berfikir kritis, gotong royong, berkebinekaan global, dan kreatif mampu diajarkan kepada peserta didik melalui aktivitas kegiatan sehari-hari di sekolah. Pendidikan karakter harus diajarkan kepada peserta didik sedini mungkin agar para penerus bangsa memiliki etika dan adab yang baik untuk Indonesia yang lebih maju.

\section{Survey Lingkungan Belajar}

Data hasil angket menyatakan bahwa para guru berusaha untuk menciptakan lingkungan belajar yang nyaman, efektif, dan menarik bagi peserta didik. Rudi mempersipakan pembelajaran dalam jaringan (daring) dengan menggunakan fasilitas gratis aplikasi pembelajaran. Nur menyatakan bahwa untuk menciptakan lingkungan belajar yang nyaman bagi peserta didik mempersiapkan sarana dan prasarana (sarpras) dengan lengkap misalnya ruang kelas yang kondusif, laboratorium dengan alat yang layak, mengatur lingkungan sekolah agar selalu asri dan lain-lain. Pada asesmen nasional guru akan menghadapi survey belajar yang bertujuan untuk mengetahui kondisi peserta didik dan guru dalam proses pembelajaran di kelas.

\section{SIMPULAN DAN SARAN}

\section{Simpulan}

Berdasarkan hasil penelitian tersebut, dapat disimpulkan hasil penelitian kelompok peserta didik menujukkan bahwa $46,6 \%$ peserta didik memahami mengenai asesmen nasional dan $53,2 \%$ peserta didik belum memahami dengan baik mengenai asesmen nasional. Hal ini disebabkan karena satuan pendidikan terkait belum melakukan sosialisasi penerapan asesmen nasional yang memiliki tiga instrumen penilaian meliputi Asesmen Kompetensi Minimum (AKM), survey belajar, dan survey lingkungan belajar. Hasil penelitian kelompok guru menyatakan bahwa $75 \%$ guru memahami mengenai asesmen nasional dan $25 \%$ guru belum memahami mengenai asesmen nasional. Asesmen nasional dilakukan untuk melakukan evaluasi terhadap input, proses, dan kualitas belajar-mengajar di kelas sehingga meningkatkan mutu pendidikan Indonesia.

\section{Saran}

Saran kepada peneliti selanjutnya dilakukan peninjauan menyeluruh oleh Pemerintah terkait penerapan assesmen nasional yang meliputi kesiapan siswa dan guru yang menjadi tolak ukur perbaikan mutu pendidikan di Indonesia. 


\section{DAFTAR RUJUKAN}

Arifin, Zainal. 2011. Evaluasi Pembelajaran Prinsip, Teknik, Prosedur. Bandung: PT Remaja Rosdakarya.

Ditjen P3GTK Kementerian Pendidikan dan Kebudayaan. 2020. Di Tengah Pandemi Virus Korona, Direktorat P3GTK Mengadakan Uji Coba Survei Karakter dan Lingkungan Belajar, (Online), (https://p3gtk.kemdikbud. go.id/konten/di-tengah-pandemi-virus-korona-direktorat-p3gtk-mengadakan-uji-coba-survei-karakterdanlingkungan-belajar-a88xihtv), diakses 17 Desember 2020.

Fraenkel, J. R., Wallen, N. E., \& Hyun, H. H. 2012. How to Design and Evaluate Research in Education8th edition. New York: Mc Graw Hill.

Hadi, Syamsul \& Novaliyosi. 2019. TIMSS Indonesia (Trends In International Mathematics And Science Study). Prosiding disajikan dalam Seminar Nasional \& Call For Papers Program Studi Magister Pendidikan Matematika, Universitas Siliwangi, Tasikmalaya, 19 Januari.

Kementerian Pendidikan dan Kebudayaan. 2019.Tahun 2021, Ujian Nasional Diganti Asesmen Kompetensi dan Survei Karakter, (Online), https://www.kemdikbud.go.id/main/blog/2019/12/tahun-2021-ujian-nasionaldiganti-asesmen-kompetensi-dan-survei-karakter, diakses 17 Desember 2020.

Kementerian Pendidikan dan Kebudayaan. 2020. Asesmen Nasional Lembar Tanya Jawab.

Kementerian Pendidikan dan Kebudayaan. 2020. Asesmen Nasional sebagai Penanda Perubahan Paradigma Evaluasi Pendidikan, (Online) https:/www.kemdikbud.go.id/main/blog/2020/10/asesmen-nasional-sebagaipenanda-perubahan-paradigma-evaluasi-pendidikan, diakses 17 Desember 2020.

Mullis, Ina V.S. Martin, Michael O. Foy, Pierre Hooper, Martin. Boston College, Chestnut Hill, MA. 2016a. TIMSS 2015 International Results in Mathematics. Boston: TIMSS \& PIRLS International Study Center.

Mullis, Ina V.S. Martin, Michael O. Foy, Pierre Hooper, Martin. Boston College, Chestnut Hill, MA. 2016 b. TIMSS 2015 International Results in Science. Boston: TIMSS \& PIRLS International Study Center.

OECD (Organisation for Economic Cooperation and Development). 2018.PISA 2018 Result. Paris: OECD Publishing.

Peraturan Menteri Pendidikan dan Kebudayaan Nomor104 Tahun 2014 tentang Penilaian Hasil Belajar oleh Pendidik pada Pendidikan Dasar DanMenengah, BSNP (online). (http://bsnp-indonesia.org/id/wp-content/ uploads/2014/11/permendikbud-no-104-tahun-2014.pdf.), diakses 24 Desember 2020.

Pusat Asesmen dan Pembelajaran Kementerian Pendidikan dan Kebudayaan. 2019. Asesmen Nasional Lembar Tanya Jawab, (Online), http://ditpsd.kemdikbud.go.id/upload/

filemanager/2020/10/Tanya\%20Jawab\%20AKM.pdf, diakses 17 Desember 2020.

Pusat Asesmen dan Pembelajaran. 2020. Asesmen Kompetensi Minimum (AKM)

Sugiyono. 2017. Metode Penelitian Kuantitatif, Kualitatif, dan R\& D. Bandung: Alfabeta.

Tan, Charlene. 2017. PISA and education reform in Shanghai. Critical Studiesin Education, 60(3), 1-15. DOI: $10.1080 / 17508487.2017 .1285336$.

Wilson,Mark. 2018. Making Measurement Important for Education: The Crucial Roleof Classroom Assessment. Educational Measurement: Issues and Practice Spring, 37(1), 5-20. DOI: https://doi.org/10.1111/emip.12188. 